\title{
ECAR-2925 AGC-2 SPECIMEN LOAD CALCULATIONS BY STACK
}

\section{February 2016}

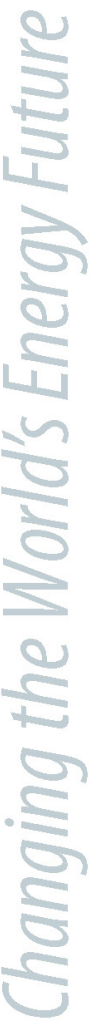

David T Rohrbaugh

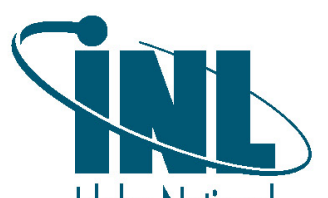

Idaho National

Laboratory 


\section{DISCLAIMER}

This information was prepared as an account of work sponsored by an agency of the U.S. Government. Neither the U.S. Government nor any agency thereof, nor any of their employees, makes any warranty, expressed or implied, or assumes any legal liability or responsibility for the accuracy, completeness, or usefulness, of any information, apparatus, product, or process disclosed, or represents that its use would not infringe privately owned rights. References herein to any specific commercial product, process, or service by trade name, trade mark, manufacturer, or otherwise, does not necessarily constitute or imply its endorsement, recommendation, or favoring by the U.S. Government or any agency thereof. The views and opinions of authors expressed herein do not necessarily state or reflect those of the U.S. Government or any agency thereof. 


\title{
ECAR-2925 AGC-2 SPECIMEN LOAD CALCULATIONS BY STACK
}

\author{
David T Rohrbaugh
}

February 2016

Idaho National Laboratory

Idaho Falls, Idaho 83415

http://www.inl.gov

Prepared for the U.S. Department of Energy

Under DOE Idaho Operations Office

Contract DE-AC07-05ID14517 
Document ID: ECAR-2925

Project No: 32138

Revision No: 0

Effective Date: 02/10/2016

INL/MIS-16-37831

\section{Engineering Calculations and Analysis}

ECAR Title: AGC-2 Specimen Load Calculations by Stack

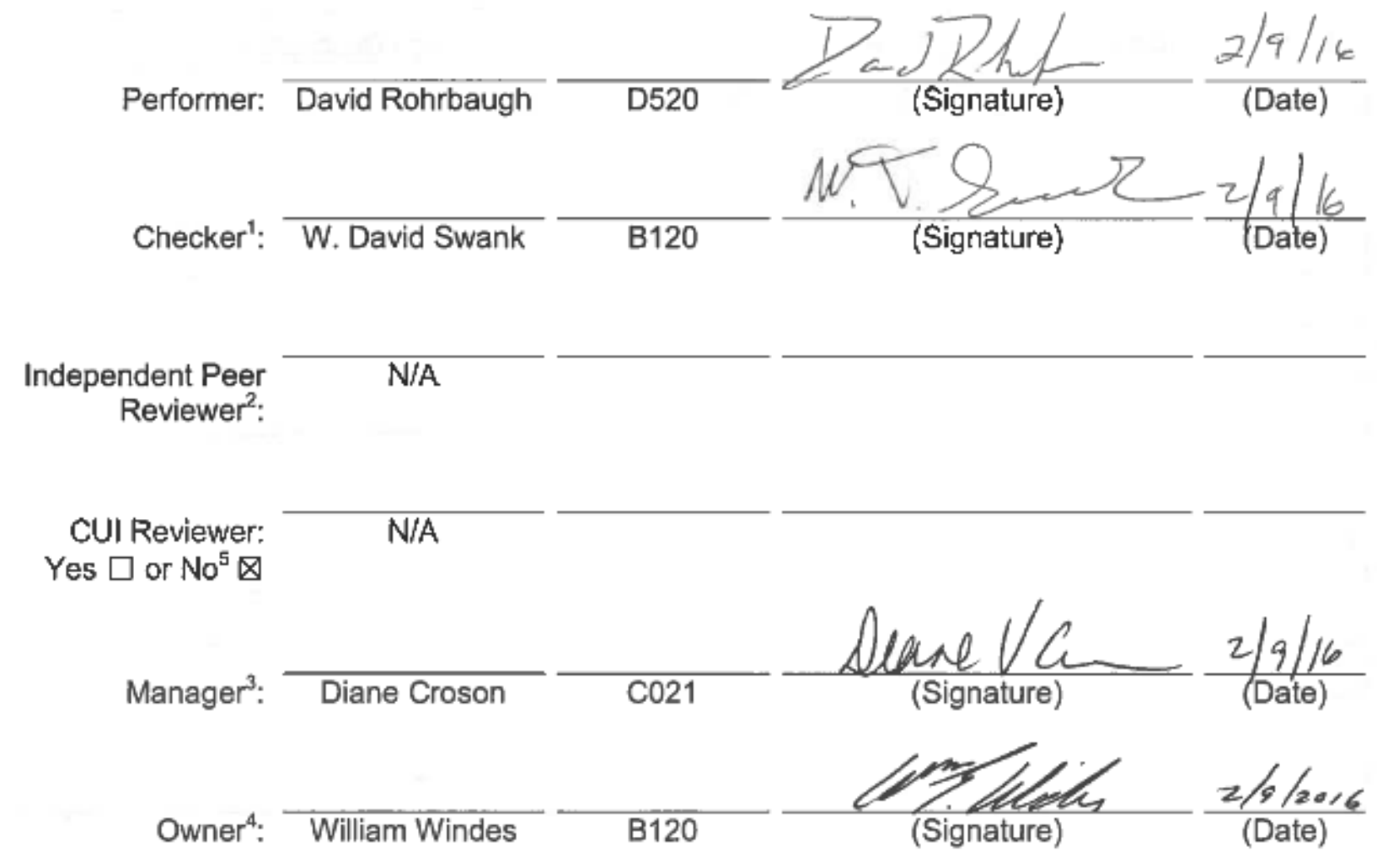

Nuclear Safety ${ }^{4}$ :

N/A

Cognizant Engineer ${ }^{4}$ :

N/A

Quality Assurance:
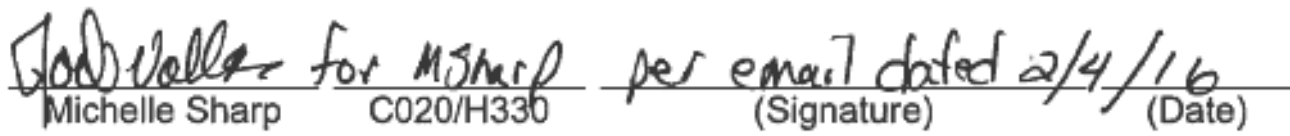

1. Confirmation of completeness, mathematical accuracy, and correctness of data and appropriateness of assumptions.

2. Concurrence of method or approach. See definition, LWP-10106.

3. Concurrence of procedure compliance. Concurrence with method/approach and conclusion.

4. Concurrence with the document's assumptions and input information. See definition of Acceptance, LWP-10200.

5. Does the document contain CUI material please check either yes or no. 
TEM-10200-1

$03 / 01 / 2012$

ENGINEERING CALCULATIONS AND ANALYSIS

Page 1 of 12

Rev. 06

Title: $\quad$ AGC-2 Specimen Load Calculations by Stack

ECAR No.: 2925

Rev. No.: 0

Project No.:

32138

Date: $02 / 10 / 2016$

REVISION LOG

\begin{tabular}{|c|c|c|l|}
\hline Rev. & Date & Affected Pages & \multicolumn{1}{c|}{ Revision Description } \\
\hline 0 & $02 / 10 / 2016$ & All & Newly issued document. \\
\hline & & & \\
\hline & & & \\
\hline & & & \\
\hline & & & \\
\hline & & & \\
\hline & & & \\
\hline & & & \\
\hline & & & \\
\hline
\end{tabular}


TEM-10200-1

$03 / 01 / 2012$

ENGINEERING CALCULATIONS AND ANALYSIS

Page 2 of 12

Rev. 06

Title: $\quad$ AGC-2 Specimen Load Calculations by Stack

$\begin{array}{lllll}\text { ECAR No.: } 2925 & \text { Rev. No.: } 0 & \text { Project No.: } 32138 \quad \text { Date: } 02 / 10 / 2016\end{array}$

\begin{tabular}{|l|c|}
\hline 1. Quality Level (QL) No. & 2 \\
\cline { 1 - 2 } 2. QL Determination No. & RTC-000486 \\
\hline 3. Engineering Job (EJ) No. & NA \\
\hline 4. SSC ID & NA \\
\hline 5. Building & NA \\
\hline 6. Site Area & NA \\
\hline
\end{tabular}

7. Objective/Purpose:

This Engineering Calculations Analysis Report (ECAR) documents the results of the summarization of the load cell data taken during the Advance Test Reactor (ATR) during Cycles 149A, 149B, 150A, 150B, 151A, 151B, and 152A. During each cycle, the specimens in the upper portion of the experiment (Stacks 1-6) were subjected to a compressive load. The applied load of each stack was monitored using six different load cells. Collecting data detailing the loads applied over the life of the experiment is necessary for use in future analyses. This load summary data will be used in creep rate estimations and post-irradiated examination (PIE) of material properties.

8. If revision, please state the reason and list sections and/or pages being affected:

NA

9. Conclusions/Recommendations:

The load data from the AGC-2 experiment were analyzed. Quantification of the data was necessary to obtain a single load value for each of the stacks of specimens. These values will be used in future analysis and characterization of material properties. The mean load values were calculated using a threshold method. This method only averaged data if it were at or above $90 \%$ of the stack's nominal load. After the averaging, the coefficient of variation (COV) was calculated for each stack. This provided an evaluation of the precision of the load cell data. The range of these COVs was between $0.7 \%$ (Stack 5 ) and $1.3 \%$ (Stacks 1 and 2 ). 
Rev. 06

Title: $\quad$ AGC-2 Specimen Load Calculations by Stack

$\begin{array}{lllll}\text { ECAR No.: } 2925 & \text { Rev. No.: } 0 & \text { Project No.: } & 32138 & \text { Date: } 02 / 10 / 2016\end{array}$

\section{CONTENTS}

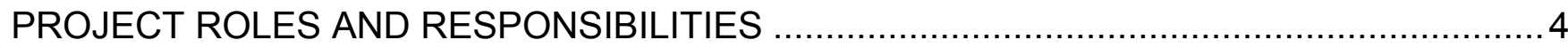

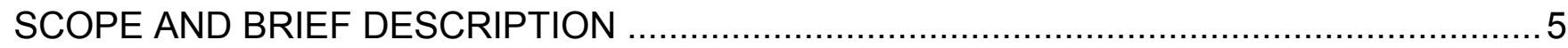

DESIGN OR TECHNICAL PARAMETER INPUT AND SOURCES ….................................

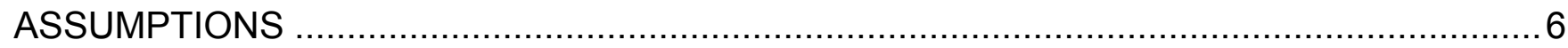

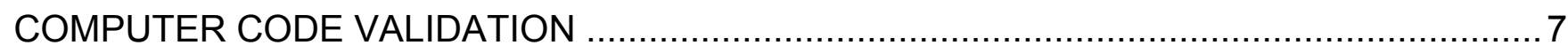

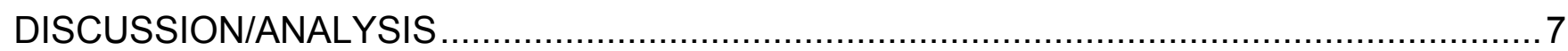

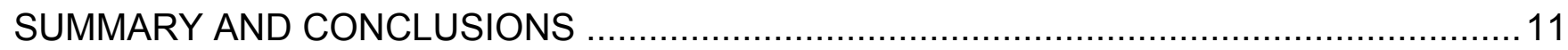

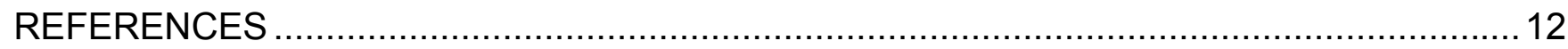

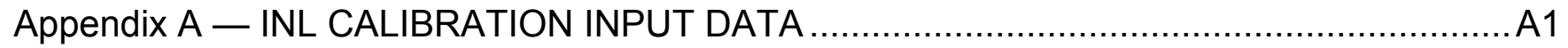

\section{FIGURES}

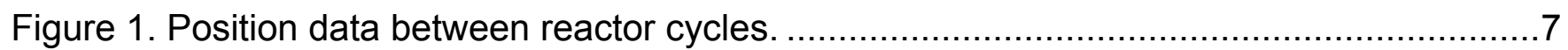

Figure 2. Time series data of load cell output from AGC-2 experiment. ....................................

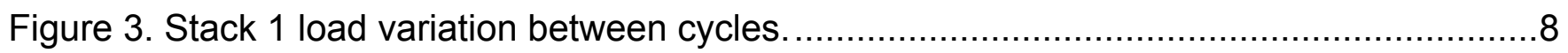

Figure 4. Distributions of load cell values for Stack 1 and Stack 4 .....................................

Figure 5. Load distribution data above threshold values for each specimen stack. .................. 9

Figure 6. Example of delay in time between power up and application of compressive load....10

Figure 7. Load averages for each stack before and after applying the threshold average. The error bars indicate $+/-1$ standard deviation in the data.

\section{TABLES}

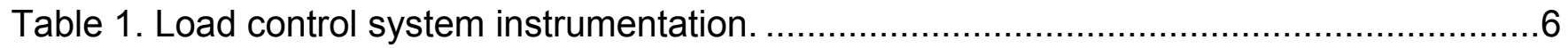

Table 2. AGC-2 MW-Days at load, averaged for each stack across every cycle.....................10

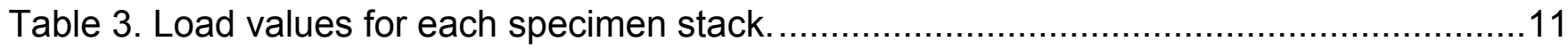

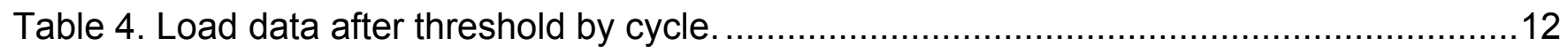


TEM-10200-1

$03 / 01 / 2012$

ENGINEERING CALCULATIONS AND ANALYSIS

Page 4 of 12

Rev. 06

Title: $\quad$ AGC-2 Specimen Load Calculations by Stack

ECAR No.: 2925

Rev. No.: 0

Project No:

32138

Date: $02 / 10 / 2016$

PROJECT ROLES AND RESPONSIBILITIES

\begin{tabular}{|c|c|c|c|}
\hline Project Role & Name (Typed) & Organization & Pages covered (if applicable) \\
\hline Performer & David Rohrbaugh & D520 & All \\
\hline Checker $^{a}$ & W. David Swank & B120 & All \\
\hline Independent Reviewer ${ }^{\mathrm{b}}$ & $N / A$ & & \\
\hline CUI Reviewer ${ }^{\mathrm{C}}$ & & & All \\
\hline Manager $^{d}$ & Diane Croson & $\mathrm{C} 021$ & \\
\hline Requestor $^{\mathrm{e}}$ & William Windes & B120 & \\
\hline Nuclear Safety & $N / A$ & & \\
\hline Document Owner ${ }^{e}$ & William Windes & B120 & \\
\hline Quality Assurance & Michelle Sharp & $\mathrm{C} 020 / \mathrm{H} 330$ & \\
\hline
\end{tabular}
a. Confirmation of completeness, mathematical accuracy, and correctness of data and appropriateness of assumptions.
b. Concurrence of method or approach. See definition, LWP-10106.
c. Concurrence with the document's markings in accordance with LWP-11202.
d. Concurrence of procedure compliance. Concurrence with method/approach and conclusion.
e. Concurrence with the document's assumptions and input information. See definition of Acceptance, LWP-10200.

NOTE: $\quad$ Delete or mark "N/A" for project roles not engaged. Include ALL personnel and their roles listed above in the eCR system. The list of the roles above is not all inclusive. If needed, the list can be extended or reduced. 
TEM-10200-1

$03 / 01 / 2012$

ENGINEERING CALCULATIONS AND ANALYSIS

Page 5 of 12

Rev. 06

Title:

AGC-2 Specimen Load Calculations by Stack

ECAR No.: 2925

Rev. No.: 0

Project No:

32138

Date: $02 / 10 / 2016$

\section{SCOPE AND BRIEF DESCRIPTION}

This Engineering Calculations Analysis Report (ECAR) documents the results of the threshold averaging on the load cell data taken during the second advanced graphite creep (AGC) experiment, AGC-2. Specimens were irradiated in the Advance Test Reactor (ATR) during Cycles 149A, 149B, $150 \mathrm{~A}, 150 \mathrm{~B}, 151 \mathrm{~A}, 151 \mathrm{~B}$, and 152A. During each cycle, the specimens located in the upper portions of the stacks were subjected to a compressive load. The applied load of each stack was monitored and load data were recorded in 5-minute intervals. The load on each stack remained relatively constant throughout the reactor cycles. However, during reactor outages, the load was removed until the beginning of the next reactor cycle. Using the load cell data, it is necessary to estimate the load applied to each stack (and therefore each specimen in each stack) for use in the creep rate calculations and post-irradiation examination (PIE) property comparisons.

\section{DESIGN OR TECHNICAL PARAMETER INPUT AND SOURCES}

1. The requirements for this analysis were the following:

a. Describe the AGC capsule mechanical loading system and verify that the system operated as designed during irradiation.

b. Calculate the compressive load imposed on the specimens for each of the outer stacks (1-6) in the AGC-2 experiment at power.

c. Describe the method used to quantify the loads for each stack.

d. Provide an estimate of the precision and accuracy of the calculated loads and the method for calculating them.

e. Evaluate the quality of the data in terms of precision, accuracy, representativeness, comparability, and completeness (PARCC).

Requirements for the AGC-2 capsule irradiation data collection are presented in three INL technical and functional requirements (TFRs): TFR-645, "Advanced Graphite Capsule AGC-2 Experimental Test Train”; TFR-509, "Advanced Graphite Capsule Temperature Control System"; and TFR-510, "Advanced Graphite Capsule Compressive Load Control Gas System." The compressive load systems are unchanged from the AGC-1 experiment and use the same TFRs. A description of the approach to the load data qualification is included in INL/EXT-1226248, "AGC-2 Irradiation Data Qualification Report."

2. Load, power, and stack position data were obtained from NGNP Data Management and Analysis System (NDMAS) from ATR starting at Cycle 149A (April 12, 2011) and ending at Cycle 151B (May 5, 2012).

3. The accuracy of the load cells that are used is $0.3 \%$ of full scale. Full scale for this model is $1000 \mathrm{lb}$, thus the accuracy is +-/ $3 \mathrm{lbs}$. During the assembly of the experiment, these load cells were Quality Assurance verified to be calibrated (Engineering Work Instructions for Assembling the AGC-2 Experiment). Both Table 1 and DWG 601266 show additional information about the instruments used in the load control system. The load cell calibration sheets are attached in Appendix A. 
TEM-10200-1

$03 / 01 / 2012$

ENGINEERING CALCULATIONS AND ANALYSIS

Page 6 of 12

Rev. 06

Title:

AGC-2 Specimen Load Calculations by Stack

ECAR No.: 2925

Rev. No.: 0

Project No:

32138

Date: $02 / 10 / 2016$

Table 1. Load control system instrumentation.

\begin{tabular}{|l|l|l|l|l|}
\hline Instrument & Manufacturer & Model/ Part No. & Accuracy or Linearity & Repeatability \\
\hline $\begin{array}{l}\text { Precision miniature } \\
\text { load cell }\end{array}$ & $\begin{array}{l}\text { Honeywell } \\
\text { Corp. }\end{array}$ & 31/AL311CV & $\begin{array}{l} \pm 0.3 \% \text { of full scale } \\
(\mathrm{FS}=1000 \mathrm{lbf} \text { ) accuracy }\end{array}$ & $\pm 0.05 \%$ full scale \\
\hline $\begin{array}{l}\text { Position Sensor } \\
\text { (LVDT) }\end{array}$ & $\begin{array}{l}\text { Macro } \\
\text { Sensors }\end{array}$ & PRH 812-1000-080 & $\begin{array}{l}\leq \pm 0.25 \% \text { of full range } \\
\text { linearity }\end{array}$ & $<0.01 \%$ of FS Output \\
\hline
\end{tabular}

\section{ASSUMPTIONS}

For this analysis, it was assumed that the specimens in each stack did not become lodged or stuck in a position that would alter the load of the remainder of the specimens in the stack. To help prevent this from happening, during reactor outages, the compressive loads are removed from the specimen stacks and each graphite stack is raised vertically. This is done by use of pneumatic rams. Stack raising was performed after Cycles 149A, 149B, 150A, 151A, and 151B and at the end of the experiment. No evidence of sticking was observed during any of those episodes (INL/EXT-12-26248). In addition, the position of each stack remained unaffected between cycles. To support this, the position data of each stack (recorded from linear variable differential transformers [LVDTs] and saved in NDMAS) were analyzed. The position magnitudes for each stack were plotted versus time. Then the LVDT values at the end of each reactor cycle were compared to the LVDT values at the beginning of the subsequent cycle. For all cycles and stacks these values were roughly the same, indicating the loaded samples remained free during the entire experiment. An example of this is shown in Figure 1, the position data of Stack 1 between Cycles 149B and 150B.

The load cylinder gas pressure was also monitored during the test. A constant specimen pressure over the duration of the experiment would indicate no degradation in any of the load cells that required a compensating change in the gas pressure. This pressure remained relatively constant throughout the experiment. However, during Cycle 151A, there was a slight decrease in the gas pressure for Stacks 13 . This led to a change in load of less than $4 \%(<15 \mathrm{lbf})$. There were maintenance activities being conducted on the pressure system during this same time period; therefore, this change in pressure is thought to be related to the maintenance activities rather than instrumentation degradation or drift. More information on the qualification of the load control system data is provided in INL/EXT-12-26248, "AGC2 Irradiation Data Qualification Report."

The condition of the load cells was checked during the assembly of the compressive load control system by performing wire-to-wire resistance checks. Load cell resistance values were measured and recorded for both the excitation and signal lines. A similar process was used on the position sensors. This is documented in the "Engineering Work Instructions for Assembling the AGC-2 Experiment." It was impossible to make similar checks on the load and monitoring system after the completion of the experiment due to disassembly actions and high levels of radiation; however, the load and position data are consistent within itself indicating that the load cells and LVDTs operated properly for the entire experiment. 
TEM-10200-1

$03 / 01 / 2012$

ENGINEERING CALCULATIONS AND ANALYSIS

Page 7 of 12

Rev. 06

Title: $\quad$ AGC-2 Specimen Load Calculations by Stack

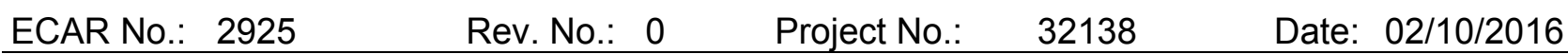

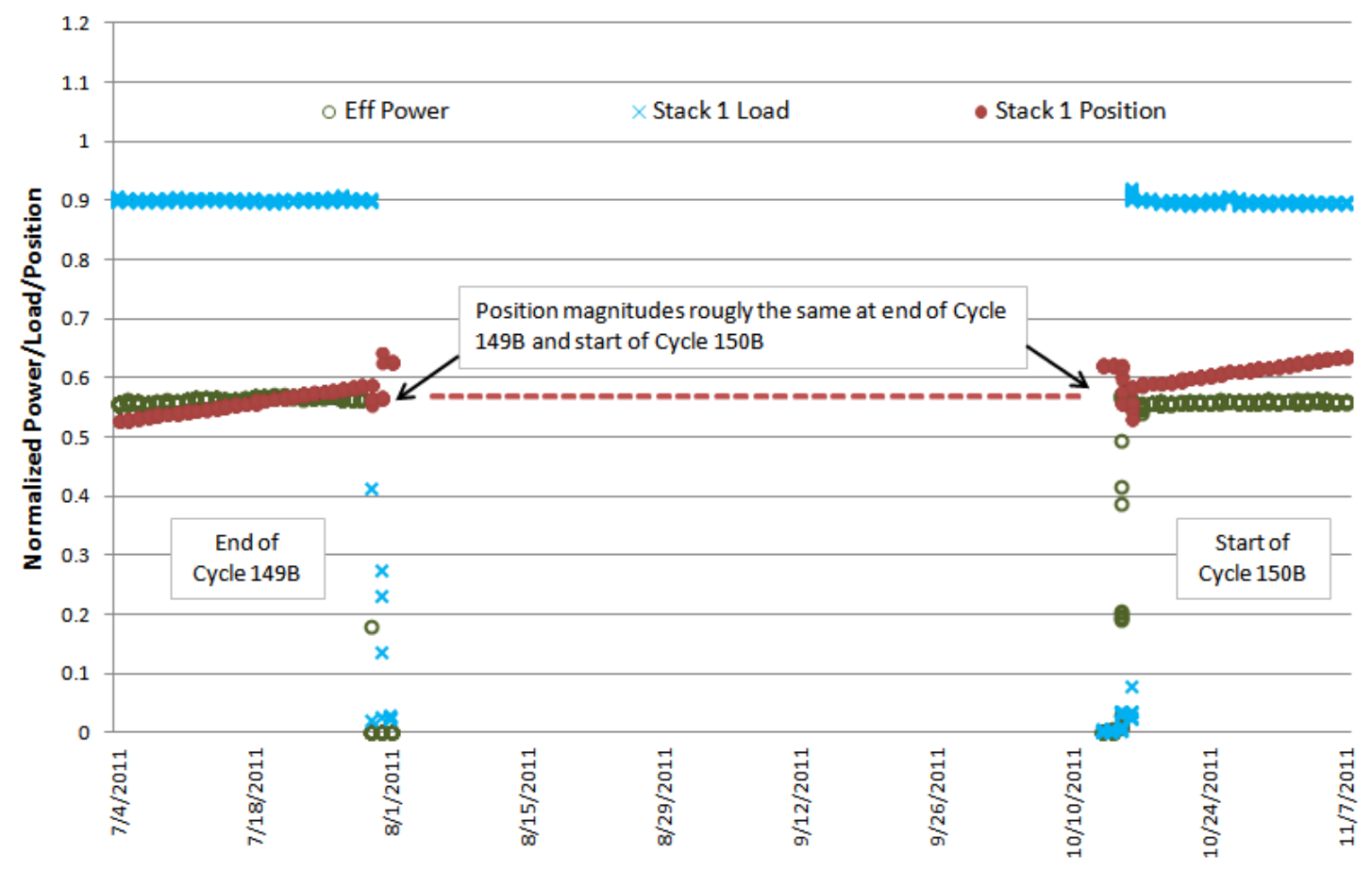

Figure 1. Position data between reactor cycles.

\section{COMPUTER CODE VALIDATION}

The "AGC2 5min Load Data ECAR-2925.xIsx" spreadsheet used load and reactor power data from NDMAS that were in 5-minute increments. The calculations were simple enough to justify using an Excel spreadsheet. The load data can be found in NDMAS. The output of the spreadsheet is an average load value for each stack (1-6) of specimens along with an uncertainty estimation. This is shown in Table 3 below. The calculations performed in the "AGC2 5min Load Data ECAR-2925.xlsx" spreadsheet were validated by random hand-calculation performed by the checker.

\section{DISCUSSIONIANALYSIS}

Load cell data from each stack of specimens in the AGC-2 experiment were recorded in 5-minute intervals and saved to NDMAS. Data logging for AGC-2 began on April 14, 2011, with Cycle 149A and ended on May 5, 2012, with Cycle 151B. For reasons unknown, there were no load cell data logged for Stack 2 in Cycle 149A from April 29, 2011, 23:00 through April 30, 2011, 22:55. Figure 2 is a history plot of the loads for each stack across all of the reactor cycles. The load data distributions were also plotted as histograms. These histograms illustrated that for each stack there were at least two modes. One of those modes is just above zero, representing the loads at the startup of each reactor cycle. In addition to the startup mode, Stacks 1, 2, and 3 had two distinct modes around their nominal loads (400 or 500 or $600 \mathrm{lbf}$ ), while Stacks 4,5 , and 6 only had a single mode. The extent of the bimodality of Stacks 1,2 , and 3 is approximately $15 \mathrm{lbf}$ peak to peak (which is at most $3.8 \%$ of the nominal load). The different modes for Stack 1 can be seen in Figure 3. Figure 4 shows the modes for Stacks 1 and 4 , while Figure 5 displays the histograms for all the stacks above threshold values. 
TEM-10200-1

$03 / 01 / 2012$

ENGINEERING CALCULATIONS AND ANALYSIS

Page 8 of 12

Rev. 06

Title: $\quad$ AGC-2 Specimen Load Calculations by Stack

ECAR No.: 2925

$\begin{array}{lll}\text { Rev. No.: } & 0 & \text { Project No.: } 32138\end{array}$

Date: $02 / 10 / 2016$

AGC-2 Load Cell Data by Stack
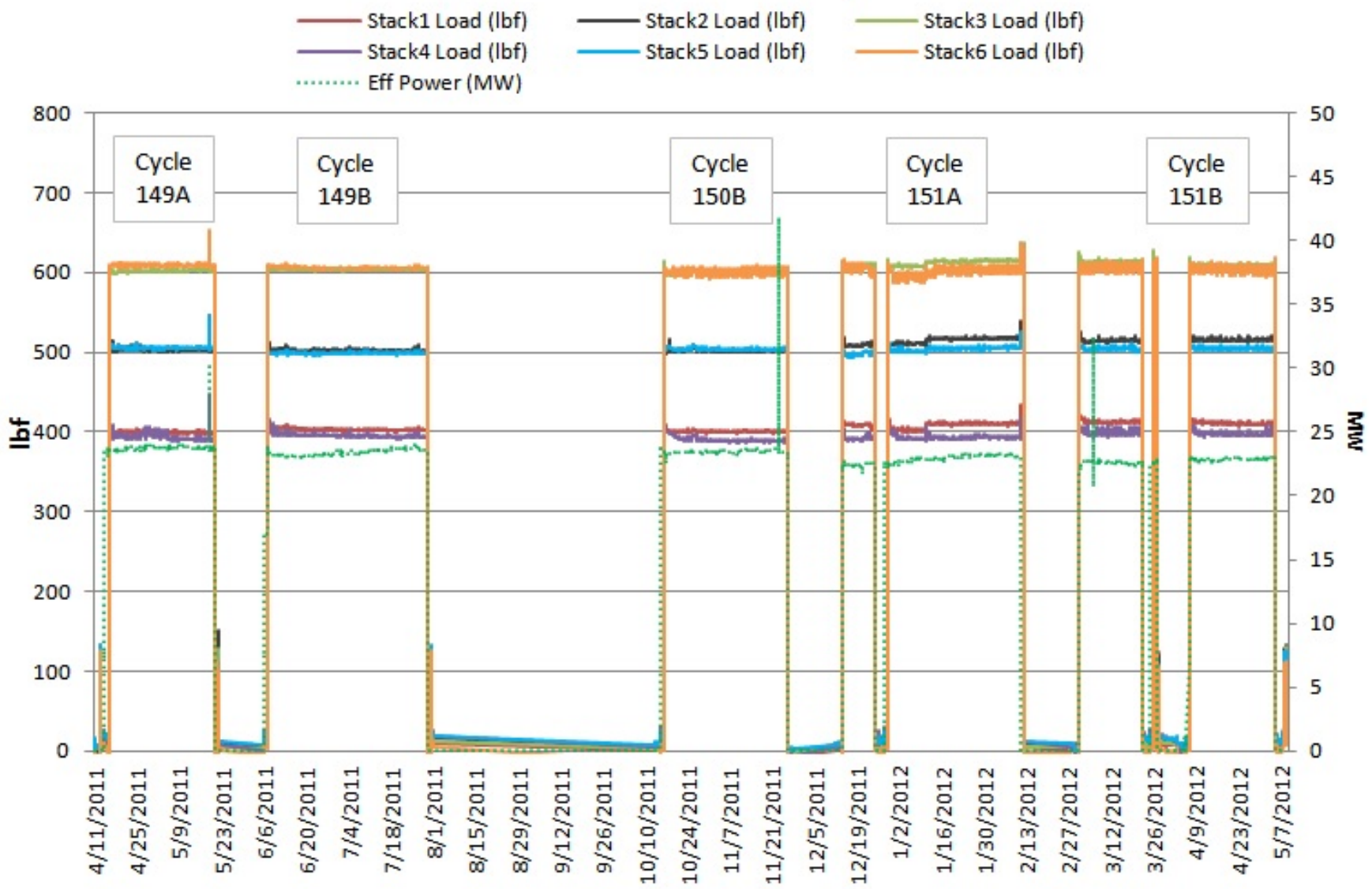

Figure 2. Time series data of load cell output from AGC-2 experiment.

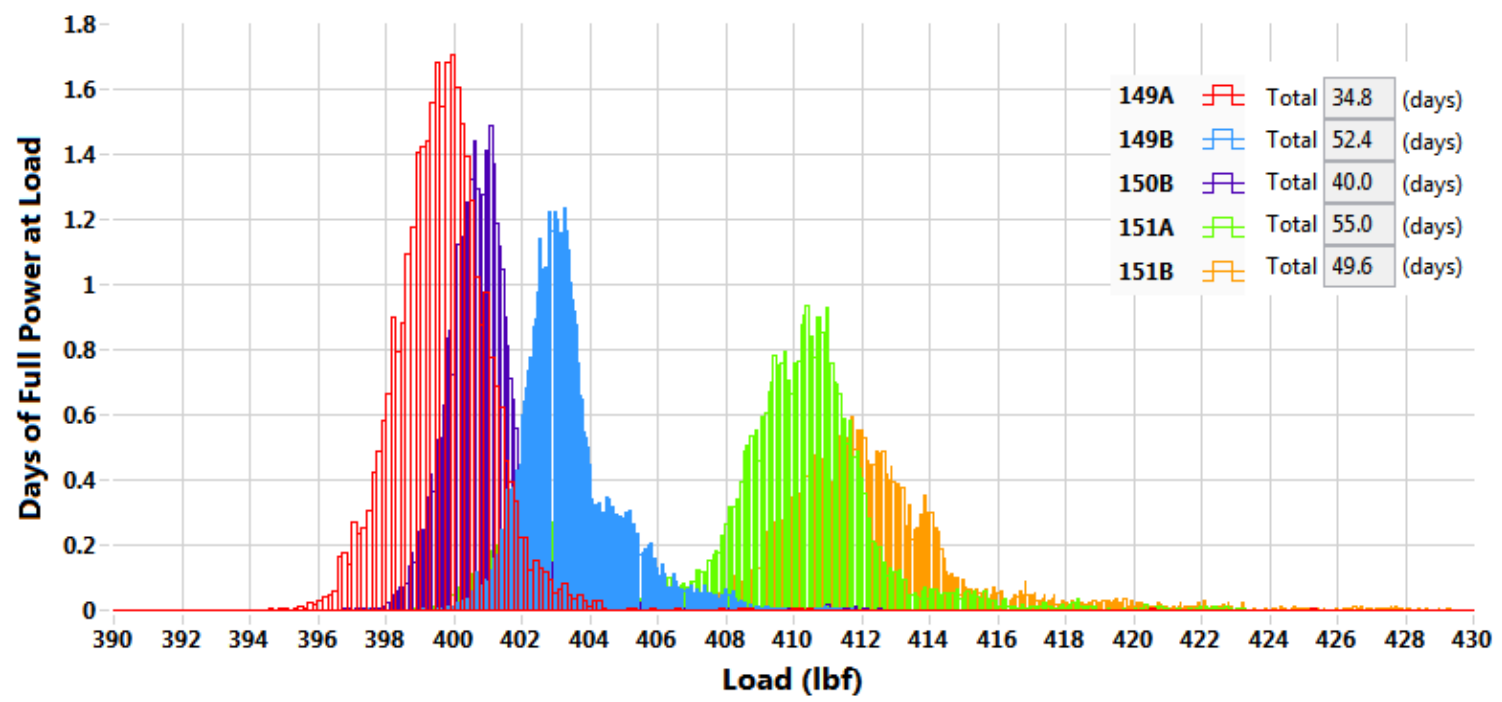

Figure 3. Stack 1 load variation between cycles. 
TEM-10200-1

$03 / 01 / 2012$

ENGINEERING CALCULATIONS AND ANALYSIS

Page 9 of 12

Rev. 06

Title: $\quad$ AGC-2 Specimen Load Calculations by Stack

$\begin{array}{lllll}\text { ECAR No.: } 2925 & \text { Rev. No.: } & 0 & \text { Project No.: } 32138 \quad \text { Date: } 02 / 10 / 2016\end{array}$

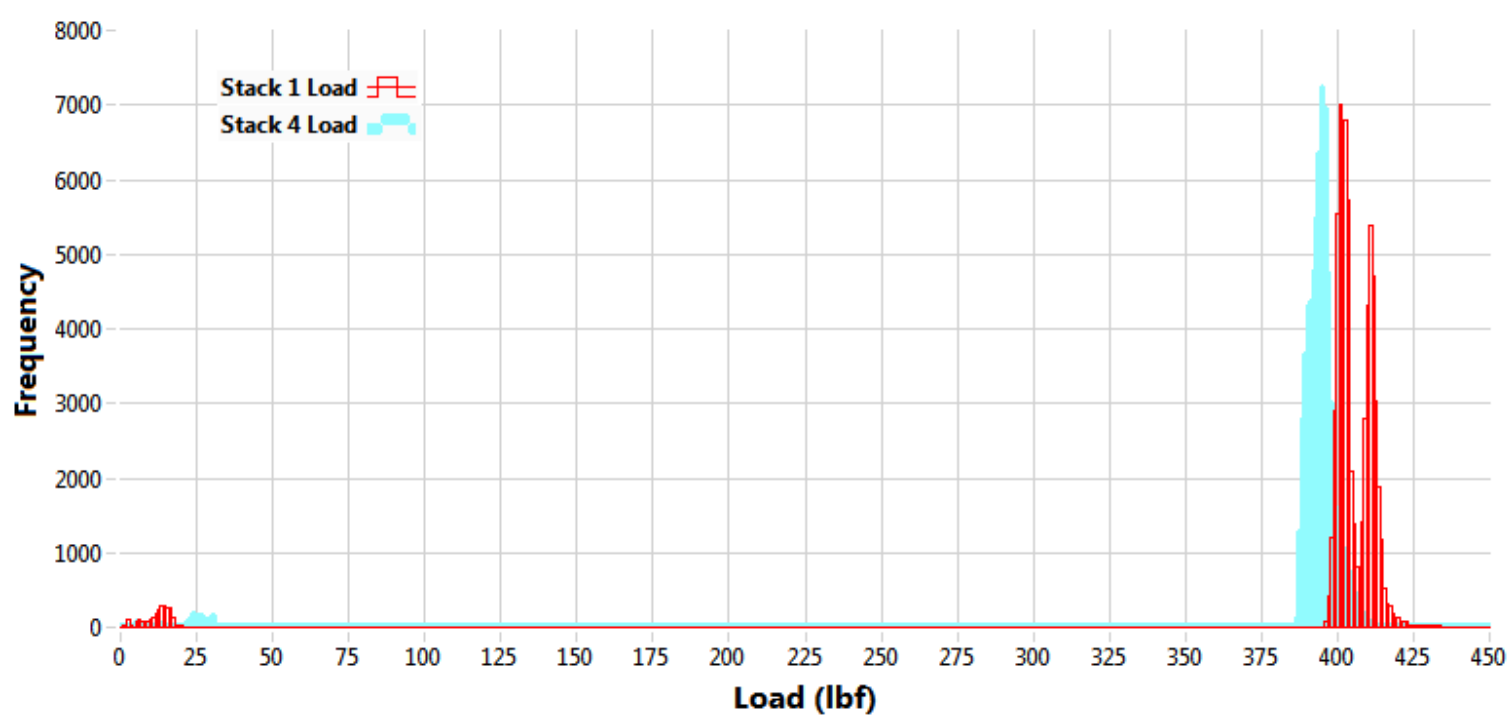

Figure 4. Distributions of load cell values for Stack 1 and Stack 4.

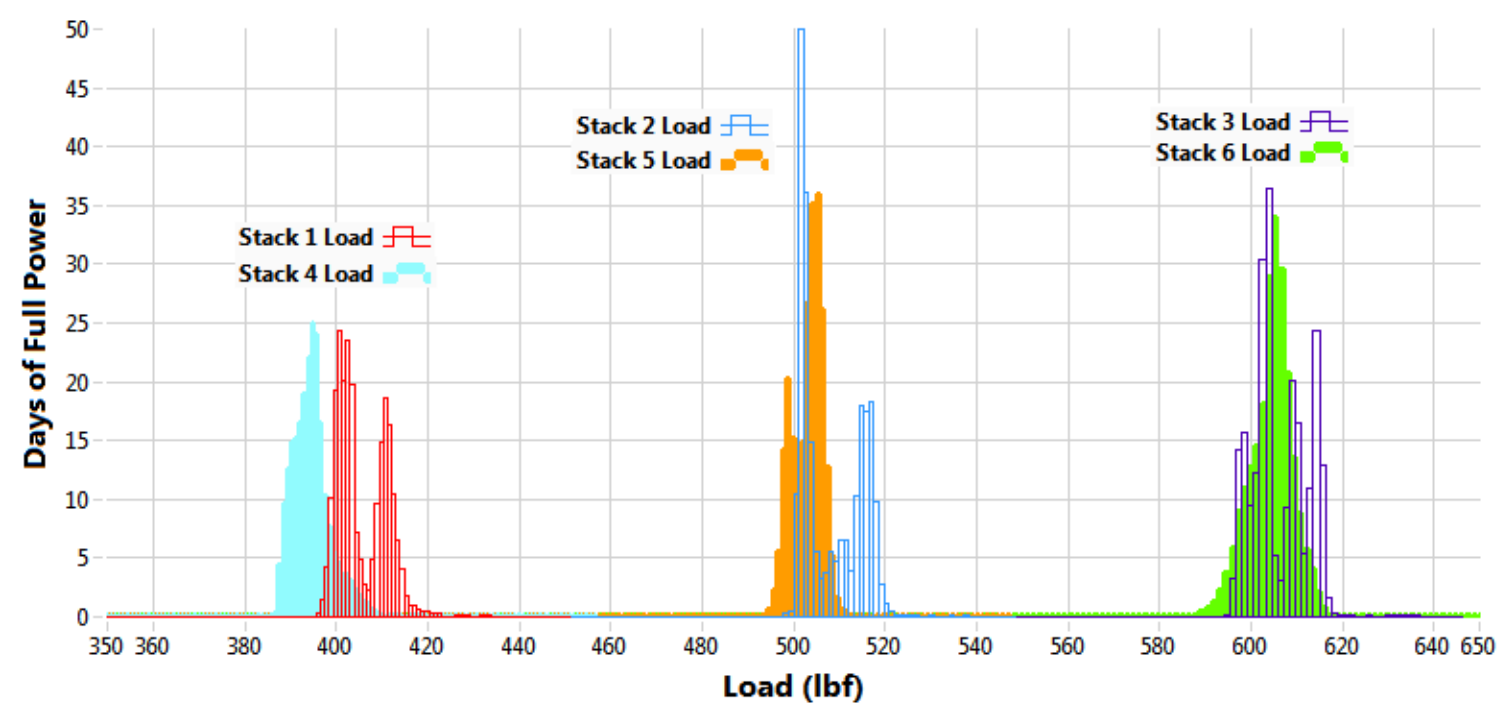

Figure 5. Load distribution data above threshold values for each specimen stack.

Upon reviewing the time series plots of the data, it was noted that at the start of each cycle there were lags in time between when the reactor came up to power and when the compressive load was applied to each stack. These delays in time were as high as 50 hours (Figure 6). With this in mind, the load averages for each stack were calculated using a threshold comparison. If the load for a stack was greater than $90 \%$ of the stack's nominal load and the power was greater than 2 megawatts (MW), then that datum point was included in the calculation of average load for the stack. Table 2 is a tabulation of the percentages of nominal loads for each stack as well as the MW-days for loads above and below those percentages. Figure 7 shows the average load of the stacks both before and after the threshold was applied. 
TEM-10200-1

$03 / 01 / 2012$

ENGINEERING CALCULATIONS AND ANALYSIS

Page 10 of 12

Rev. 06

Title: $\quad$ AGC-2 Specimen Load Calculations by Stack

$\begin{array}{llllll}\text { ECAR No.: } 2925 & \text { Rev. No.: } & 0 & \text { Project No.: } & 32138 & \text { Date: } 02 / 10 / 2016\end{array}$

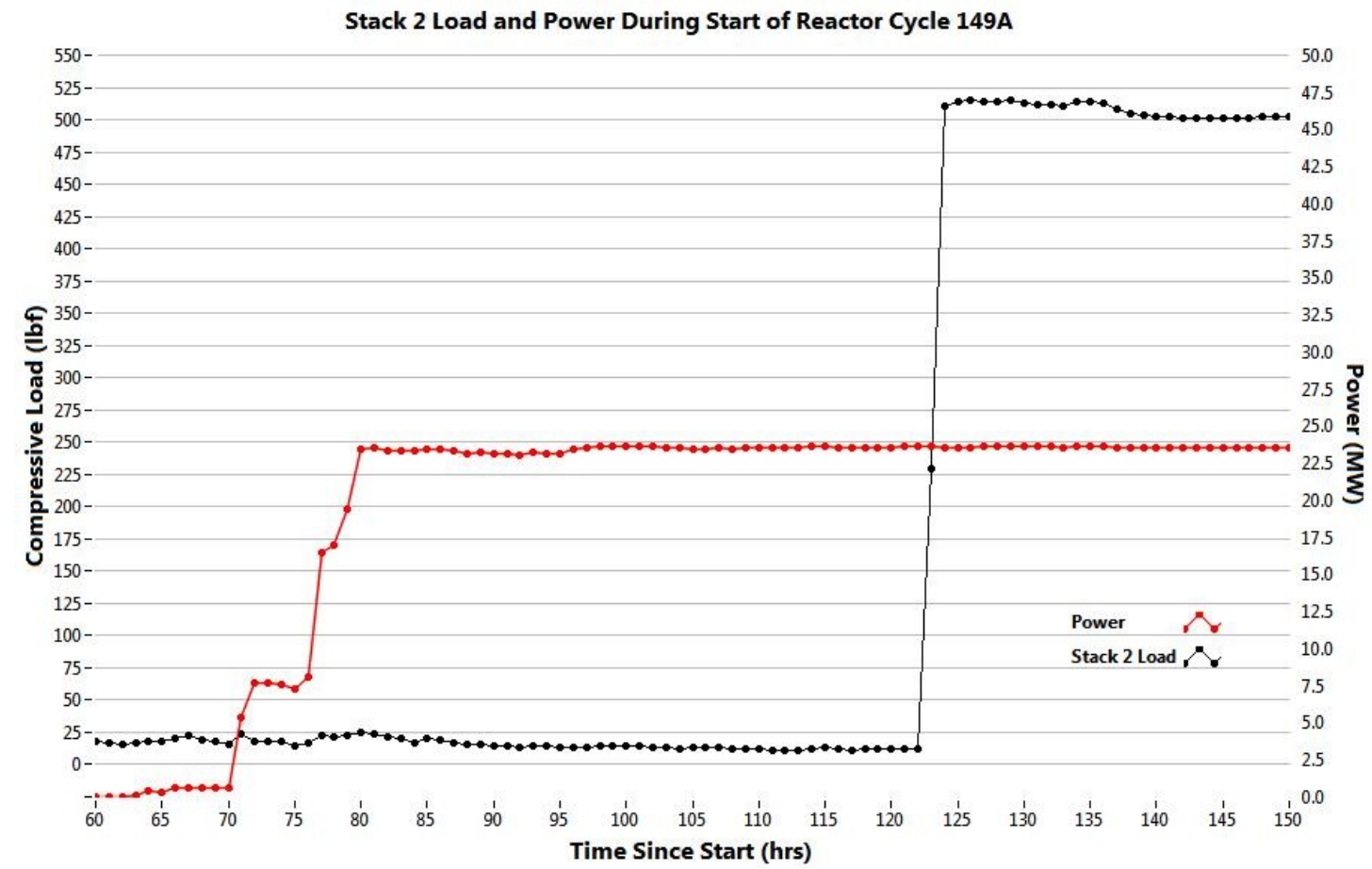

Figure 6. Example of delay in time between power up and application of compressive load.

Table 2. AGC-2 MW-Days at load, averaged for each stack across every cycle.

\begin{tabular}{|l|r|r|r|r|r|r|}
\hline & \multicolumn{1}{l|}{ Stack 1 } & \multicolumn{1}{l|}{ Stack 2 } & \multicolumn{1}{l|}{ Stack 3 } & \multicolumn{1}{l|}{ Stack 4 } & \multicolumn{1}{l|}{ Stack 5 } & \multicolumn{1}{l|}{ Stack 6 } \\
\hline 90\% of Nominal Load & 360 & 450 & 540 & 360 & 450 & 540 \\
\hline MW-Days at Load & 1075.8 & 1070.8 & 1074.8 & 1075.8 & 1075.6 & 1074.8 \\
\hline All other MW-Days & 32.0 & 32.3 & 33.0 & 32.0 & 32.3 & 33.0 \\
\hline
\end{tabular}

The motivation for using these criteria was to only consider load during the periods when the reactor was at power and the specimens were subjected to higher levels of neutrons. The time at power without load was limited to approximately $3 \%$. The following equation was implemented in Excel to calculate the load averages.

$\frac{1}{n} * \sum_{i=1}^{n} x_{i}$

for $x_{i}>0.9^{*} N L$ and $p_{i}>P T$,

where $x_{i}=$ load at time $i$,

$p_{i}=$ power at time $i$,

$N L=$ nominal load,

$P T=$ power threshold

The quality of the load data taken was evaluated using the PARCC parameters. These parameters are used to validate the data's usability. 
TEM-10200-1

$03 / 01 / 2012$

Rev. 06

Title:

AGC-2 Specimen Load Calculations by Stack

ECAR No.: 2925

Rev. No.: 0

Project No.:

32138

Date: 02/10/2016

The precision of the load data was measured by calculating the standard deviation. To compare the precision among the stacks with different nominal loads, the coefficient of variation (COV) was calculated. The range of these COVs was between $0.7 \%$ (Stack 5) and $1.3 \%$ (Stacks 1 and 2). The magnitude of the COVs was all on the same order, indicating the consistency between stack loads and good repeatability with each stack. Table 3 shows the calculated average loads with the COVs and the standard deviations. The accuracy of the data is quantified from the specifications of the load cells used in the experiment. As stated above, the load cells used had an accuracy of $+/-0.3 \%$ of full-scale reading.

Representativeness is an evaluation of the data acquisition for its ability to capture or represent the true load applied to each of the stacks. In this case, the ram pressures were monitored concurrently with the load. They remained consistent over the experiment, which indicated that there was no loss of pressure that would affect the load. Thus, it is reasonable to conclude that the acquired load data represents the actual load applied.

Completeness is a quantitative measure that evaluates how much of the data were acquired versus how much of the data were planned to be acquired. In the AGC-2 experiment, data logging began on April 14, 2011 and ended on May 5, 2012, with data saved in 5-minute increments. With exception of Stack 2, the data were successfully acquired and saved. For reasons unknown, there was no load cell data logged for Stack 2 in Cycle 149A from April 29, 2011, 23:00 through April 30, 2011, 22:55.

Comparability is a qualitative parameter that assesses the consistency of the data acquisition and analysis between experiments. The instrumentation and data acquisition rates in the AGC-2 control system are the same for all AGC experiments; thus, the load data acquired will be directly comparable to the load data from other AGC experiments. The method outlined in this ECAR will serve as a template for future AGC load analyses.

\section{SUMMARY AND CONCLUSIONS}

The load data from the AGC-2 experiment were analyzed. Quantification of the data was necessary to obtain a single load value for each of the stacks of specimens. These values will be used in future analysis and characterization of material properties. The mean load values were calculated using a threshold method. This calculation only averaged data if the data were at or above $90 \%$ of the nominal load and the reactor power was above $2 \mathrm{MW}$. Table 3 shows the load values before and after the thresholding. Table 4 shows the load after thresholding by cycle.

Table 3. Load values for each specimen stack.

\begin{tabular}{|l|r|r|r|r|r|r|}
\hline Before Threshold Statistics & \multicolumn{1}{|c|}{ Stack 1 } & \multicolumn{1}{c|}{ Stack 2 } & \multicolumn{1}{l|}{ Stack 3 } & \multicolumn{1}{l|}{ Stack 4 } & \multicolumn{1}{l|}{ Stack 5 } & \multicolumn{1}{l|}{ Stack 6 } \\
\hline Average (lbf) & 390 & 489 & 582 & 380 & 484 & 580 \\
\hline 2*Std Dev (lbf) & 76 & 96 & 116 & 72 & 94 & 118 \\
\hline Coefficient of Variance (\%) & 9.8 & 9.8 & 10.0 & 9.5 & 9.7 & 10.1 \\
\hline After Threshold Statistics & Stack 1 & Stack 2 & Stack 3 & Stack 4 & Stack 5 & Stack 6 \\
\hline Average (lbf) & 406 & 508 & 606 & 395 & 503 & 604 \\
\hline 2*Std Dev (Ibf) & 11 & 13 & 12 & 9 & 7 & 10 \\
\hline Coefficient of Variance (\%) & 1.3 & 1.3 & 1.0 & 1.1 & 0.7 & 0.8 \\
\hline
\end{tabular}


TEM-10200-1

$03 / 01 / 2012$

ENGINEERING CALCULATIONS AND ANALYSIS

Page 12 of 12

Rev. 06

Title: $\quad$ AGC-2 Specimen Load Calculations by Stack

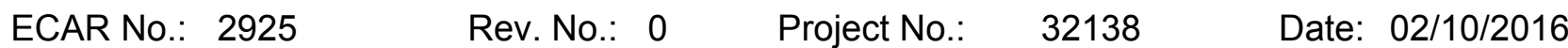

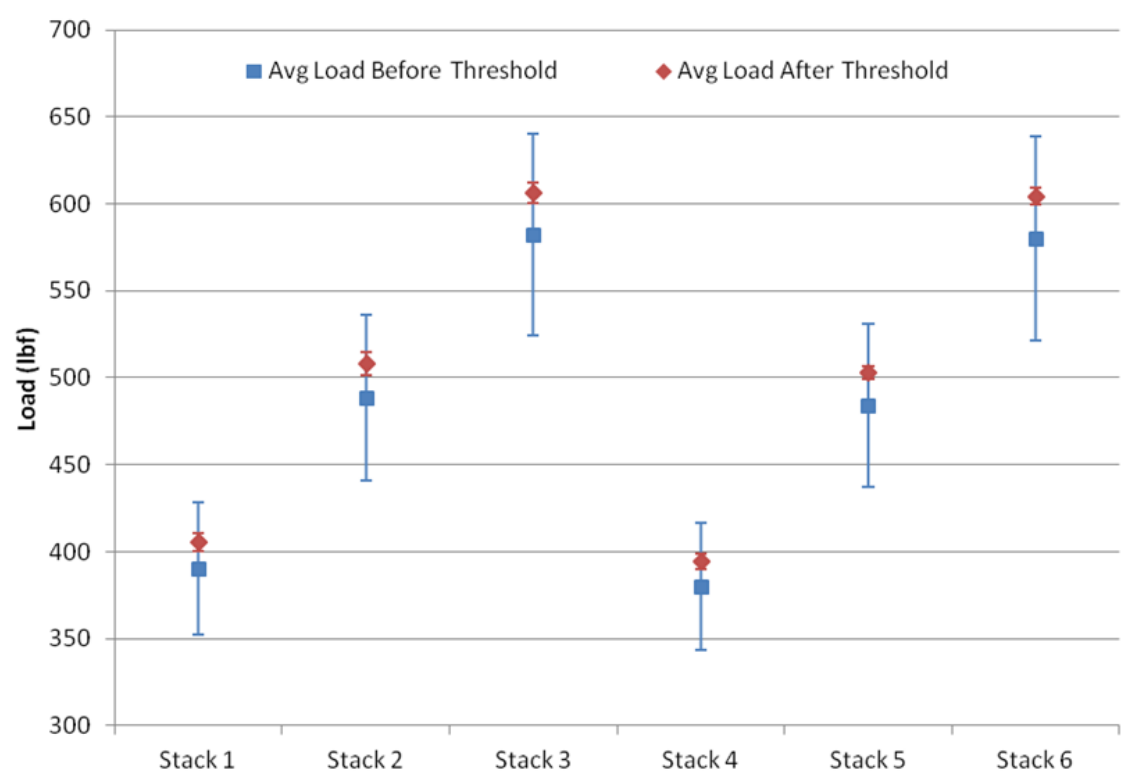

Figure 7. Load averages for each stack before and after applying the threshold average. The error bars indicate $+/-1$ standard deviation in the data.

Table 4. Load data after threshold by cycle.

\begin{tabular}{|l|r|r|r|r|r|r|}
\hline Cycle & Stack 1 (Ibf) & Stack 2 (Ibf) & Stack 3 (lbf) & Stack 4 (Ibf) & Stack 5 (Ibf) & Stack 6 (Ibf) \\
\hline 149A & 400 & 504 & 602 & 394 & 506 & 609 \\
\hline 149B & 403 & 502 & 603 & 396 & 499 & 606 \\
\hline 150B & 401 & 502 & 598 & 391 & 504 & 601 \\
\hline 151A & 409 & 514 & 612 & 393 & 503 & 602 \\
\hline 151B & 412 & 515 & 611 & 399 & 505 & 605 \\
\hline
\end{tabular}

\section{REFERENCES}

1. LWP-10200, "Engineering Calculations and Analysis Report," Rev. 7, April 10, 2012.

2. INL/EXT-12-26248, “AGC-2 Irradiation Data Qualification Final Report,” July 2012.

3. DWG 601266, "ATR Advanced Graphite Capsule Number 2 (AGC-2) Capsule Facility Assemblies," November 16, 2010.

4. "Engineering Work Instructions for Assembling the AGC-2 Experiment WO 137268-01"

5. TFR-509, “Advanced Graphite Capsule Temperature Control System”

6. TFR-510, “Advanced Graphite Capsule Compressive Load Control Gas System”

7. TFR-645, “Advanced Graphite Capsule (AGC-2) Experimental Test Train” 
TEM-10200-1

$03 / 01 / 2012$

ENGINEERING CALCULATIONS AND ANALYSIS

Page $A 1$ of $A 6$

Rev. 06

Title: $\quad$ AGC-2 Specimen Load Calculations by Stack

ECAR No.: 2925

Rev. No.: 0

Project No::

32138

Date: $02 / 10 / 2016$

\section{Appendix A}

\section{INL CALIBRATION INPUT DATA}

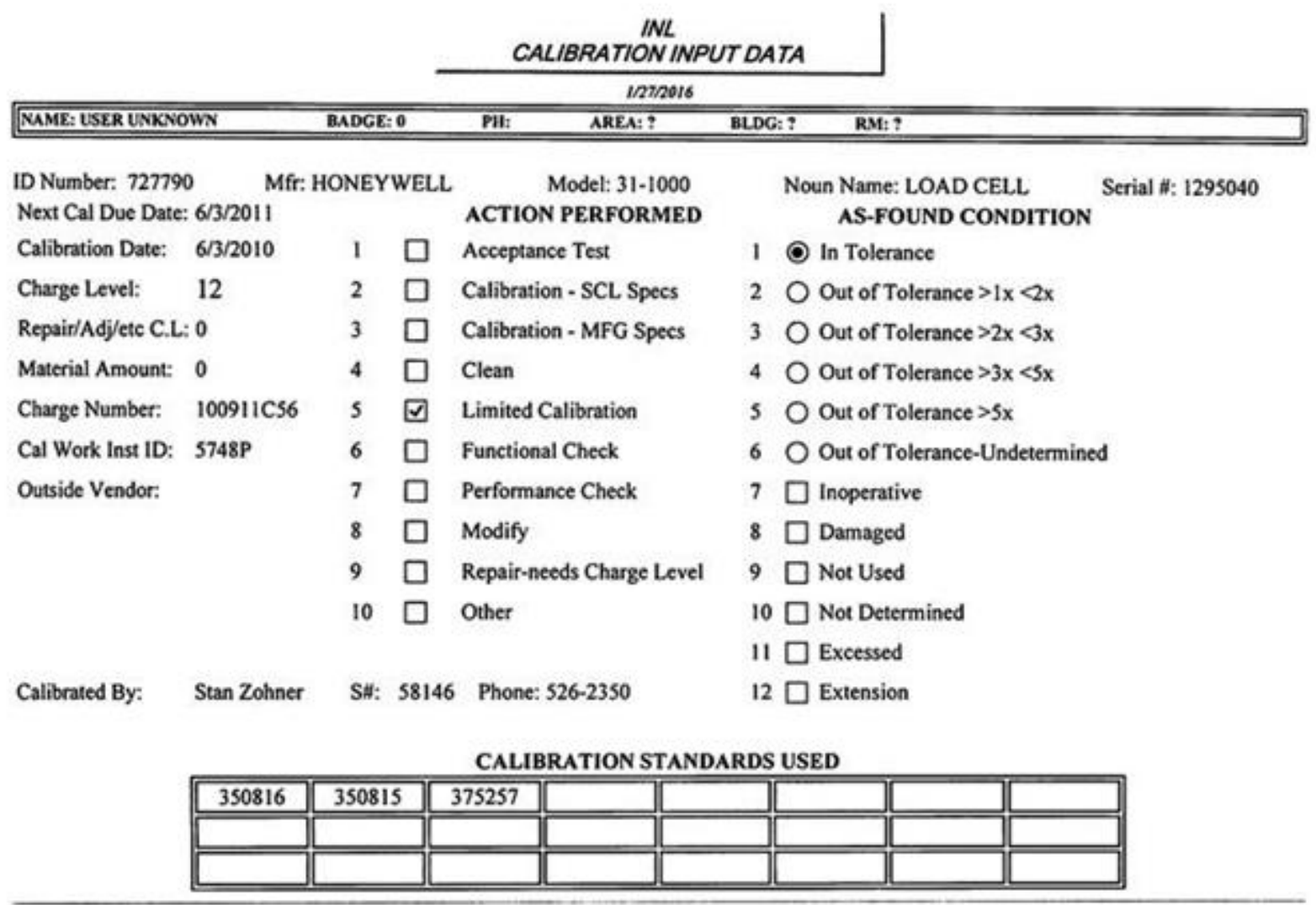

STANDARDS USED ARE TRACEABLE TO THE NATIONAL INSTITUTE OF STANDARDS AND TECHNOLOGY DERIVED FROM ACCEPTED VALUES FOR NATURAL. PHYSICAL, CONSTANTS, OR DERIVED FROM THE RATIO TYPE OF SELF CALIRRATION TECUNIQUES.

\begin{tabular}{|c|c|c|c|}
\hline \multicolumn{4}{|c|}{ LABORATORY TEMPERATURE AND HUMIDITY } \\
\hline Phrical STD (IOSC) & $(20.0 \pm 0.3)^{\circ} \mathrm{C}(40$ 10 55) $56 \mathrm{RH} \mid$ & Electronic STD (106D) & $(23.0 \pm 0.5)^{*} \mathrm{C}(30$ t0 45) \%RH \\
\hline Dimendional STD (106B) & $(20.0 \pm 0.25)^{*} \mathrm{C}(30$ t0 45) $\mathrm{Nen} \mathrm{|}$ & Electronic CAL (Lab 112) & $(23.0 \times 1.0)^{*} \mathrm{C}(2010.50) \times R H$ \\
\hline Mysidim CAL (La III) & $(20.0 \pm 05)^{\circ} \mathrm{C}(20$ to 50$) \mathrm{ssRH}$ & Remaining SteCL calibration areas: & $(230+5,-3)^{*} \mathrm{C}(20 \mathrm{H} 50) \% R \mathrm{H}$ \\
\hline
\end{tabular}

Masofacturer's eavireamental specificatioas are evaluated for coaformance when calitrations are performed eatuide the above stated ceaditions.

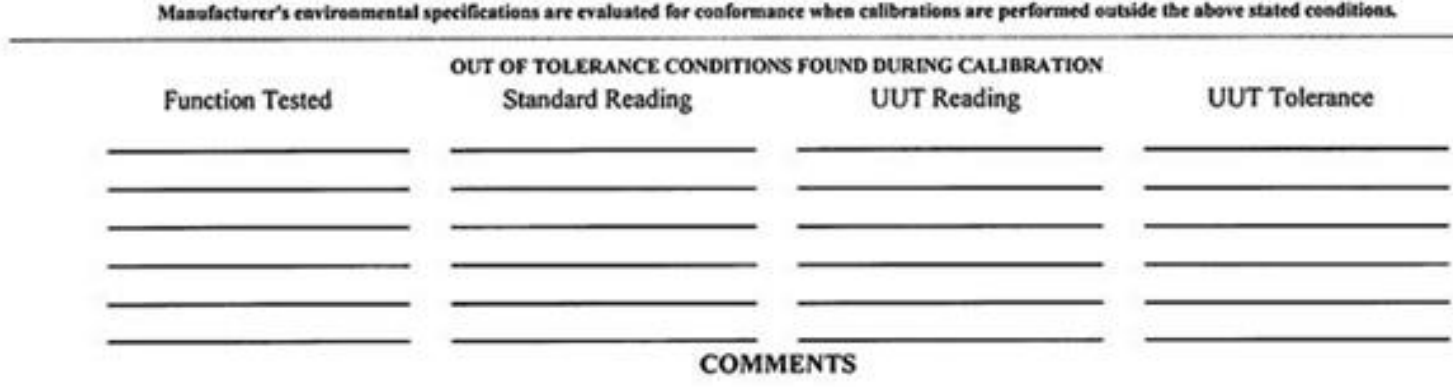

TMITIAL CALTBRATION.

LIMIEO: KUST USE NEW COEFFICTENTS GERERATEDI A= 2.220702093E-1

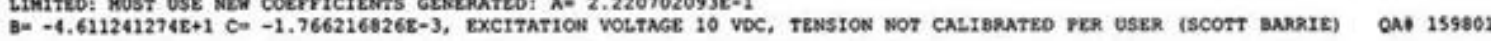


TEM-10200-1

$03 / 01 / 2012$

ENGINEERING CALCULATIONS AND ANALYSIS

Page $A 2$ of $A 6$

Rev. 06

Title: $\quad$ AGC-2 Specimen Load Calculations by Stack

ECAR No.: 2925

Rev. No.: 0

Project No.:

32138

Date: $02 / 10 / 2016$

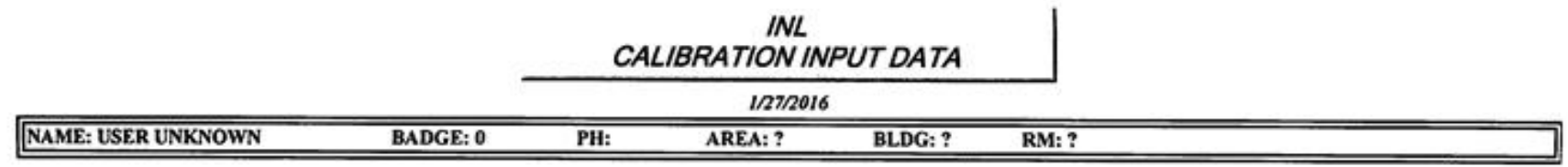

ID Number: 727788 Mfr: HONEYWELL

Model: $31-1000$

Noun Name: LOAD CELL Serial \#: 1295041

Next Cal Due Date: 6/3/2011

ACTION PERFORMED

AS-FOUND CONDITION

Calibration Date: $\quad 6 / 3 / 2010$

$1 \square$ Acceptance Test

1 In Tolerance

Charge Level: $\quad 12$

Repair/Adj/etc C.L: 0

$2 \square$ Calibration-SCL Specs

$2 \bigcirc$ Out of Tolerance $>1 x<2 x$

Material Amount: 0

$3 \square$ Calibration-MFG Specs

3 Out of Tolerance $>2 x<3 x$

Charge Number: $100911 \mathrm{C} 56$

$4 \square$ Clean

Cal Work Inst ID: $5748 \mathrm{P}$

v Limited Calibration

4 Out of Tolerance $>3 x<5 x$

Outside Vendor:

$6 \square$ Functional Check

5 Out of Tolerance $>5 x$

$7 \square$ Performance Check

6 Out of Tolerance-Undetermined

Outside Vendor:

$8 \square$ Modify

$7 \square$ Inoperative

$8 \square$ Damaged

$9 \square$ Repair-needs Charge Level

$9 \square$ Not Used

$10 \square$ Other

$10 \square$ Not Determined

$11 \square$ Excessed

Calibrated By:

Stan Zohner

SH: 58146 Phone: 526-2350

$12 \square$ Extension

CALIBRATION STANDARDS USED

\begin{tabular}{|l|l|l|l|l|l|l||l||}
\hline 350816 & 350815 & 375257 & & & & & \\
\hline & & & & & & & \\
\hline & & & & & & & \\
\hline
\end{tabular}

STANDARDS USED ARE TRACEABLE TO THE NATIONAL INSTITUTE OF STANDARDS AND TECHNOLOGY DERIVED FROM ACCEPTED VALUES FOR NATURAL PHYSICAL CONSTANTS, OR DERIVED FROM THE RATIO TYPE OF SELF CALIBRATION TECHNIQUES.

\begin{tabular}{|c|c|c|c|}
\hline \multicolumn{4}{|c|}{ LABORATORY TEMPERATURE AND HUMIDITY } \\
\hline Physical STD (106C) & $(20.0 \pm 0.3)^{\circ} \mathrm{C}(40$ to 55$) \% \mathrm{RH}$ & Electronic STD (106D) & $(23.0 \pm 0.5)^{\circ} \mathrm{C}(30$ to 45$) \% \mathrm{RH}$ \\
\hline Dimensional STD (106B) & $(20.0 \pm 0.25)^{\circ} \mathrm{C}(30$ to 45$) \% R H$ & Electronic CAL (Lab 112) & $(23.0 \pm 1.0)^{\circ} \mathrm{C}(20$ to 50$) \% \mathrm{RH}$ \\
\hline Phys/Dim CAL (Lab III) & $(20.0 \pm 0.5)^{\circ} \mathrm{C}(201050) \% \mathrm{RH}$ & Remaining S\&CL calibration areas: & $(23.0+5,-3)^{\circ} \mathrm{C}(20$ to 50$) \% \mathrm{RH}$ \\
\hline \multicolumn{4}{|c|}{ Manufacturer's environmental specinications are evaluated for conformance when ealibrations are performed outside the above stated conditions. } \\
\hline
\end{tabular}

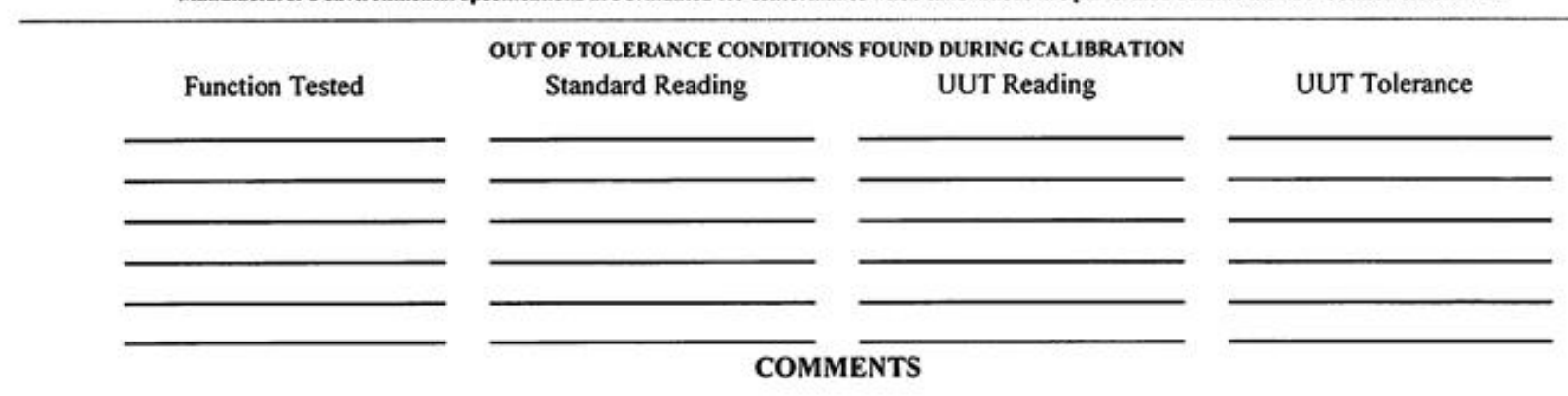

INITIAL CALIBRATION.

LIMITED: MOST USE NEW COEFFICIENTS GENERATED: A* $-2.065851653 \mathrm{E}-1$

$B=-4.706424142+1 \mathrm{Ca}-5.0144796918-3$, EXCITATION VOLTAGE $10 \mathrm{VDC}$, TENSION NOT CALIBRATED PER USER (SCOTT BARRIE)

QAF 159801 
TEM-10200-1

$03 / 01 / 2012$

ENGINEERING CALCULATIONS AND ANALYSIS

Page $A 3$ of $A 6$

Rev. 06

Title: $\quad$ AGC-2 Specimen Load Calculations by Stack

$\begin{array}{lllll}\text { ECAR No.: } 2925 & \text { Rev. No.: } & 0 & \text { Project No.: } & 32138\end{array}$

Date: $02 / 10 / 2016$

\begin{tabular}{|c|c|c|c|c|c|}
\hline & & & IN & T DATA & \\
\hline & & & $1 / 27 /$ & & \\
\hline NAME: USER UNKNOWN & BADGE: 0 & PH: & AREA:? & BLDG:? & RM:? \\
\hline
\end{tabular}

\begin{tabular}{|c|c|c|c|c|c|c|}
\hline \multirow{2}{*}{\multicolumn{2}{|c|}{$\begin{array}{l}\text { ID Number: } 727817 \\
\text { Next Cal Due Date: } 6 / 8 / 2011\end{array}$}} & \multicolumn{2}{|c|}{ Mfr: HONEYWELL } & \multirow{2}{*}{\multicolumn{2}{|c|}{$\begin{array}{c}\text { Model: } 31-1000 \\
\text { ACTION PERFORMED }\end{array}$}} & \multirow{3}{*}{$\begin{array}{l}\text { Noun Name: LOAD CELL } \\
\text { AS-FOUND CONDITION } \\
\text { In Tolerance }\end{array}$} \\
\hline & & & & & & \\
\hline Calibration Date: & $6 / 8 / 2010$ & 1 & $\square$ & Acceptance Test & 1 & \\
\hline Charge Level: & 12 & 2 & $\square$ & Calibration - SCL Specs & 2 & Out of Tolerance $>1 x<2 x$ \\
\hline \multicolumn{2}{|c|}{ Repair/Adj/etc C.L: 0} & 3 & $\square$ & Calibration - MFG Specs & 3 & Out of Tolerance $>2 x<3 x$ \\
\hline Material Amount: & 0 & 4 & $\square$ & Clean & 4 & Out of Tolerance $>3 x<5 x$ \\
\hline Charge Number: & $100911 \mathrm{C} 56$ & 5 & $\nabla$ & Limited Calibration & 5 & Out of Tolerance $>5 x$ \\
\hline Cal Work Inst ID: & $5748 \mathrm{P}$ & 6 & $\square$ & Functional Check & 6 & Out of Tolerance-Undetermined \\
\hline \multirow[t]{5}{*}{ Outside Vendor: } & & 7 & $\square$ & Performance Check & 7 & $\square$ Inoperative \\
\hline & & 8 & $\square$ & Modify & 8 & $\square$ Damaged \\
\hline & & 9 & $\square$ & Repair-needs Charge Level & 9 & $\square$ Not Used \\
\hline & & 10 & $\square$ & Other & 10 & $\square$ Not Determined \\
\hline & & & & & 11 & $\square$ Excessed \\
\hline Calibrated By: & Stan Zohner & SH: & 58146 & Phone: $526-2350$ & 12 & $\square$ Extension \\
\hline
\end{tabular}

CALIBRATION STANDARDS USED

\begin{tabular}{|l|l|l|l|l|l||l|l||}
\hline 350816 & 350815 & 375257 & & & & & \\
\hline & & & & & & & \\
\hline & & & & & & & \\
\hline
\end{tabular}

STANDARDS USED ARE TRACEABLE TO THE NATIONAL INSTITUTE OF STANDARDS AND TECHNOLOGY DERIVED FROM ACCEPTED VALUES FOR NATURAL PHYSICAL CONSTANTS, OR DERIVED FROM THE RATIO TYPE OF SELF CALIBRATION TECHNIQUES.

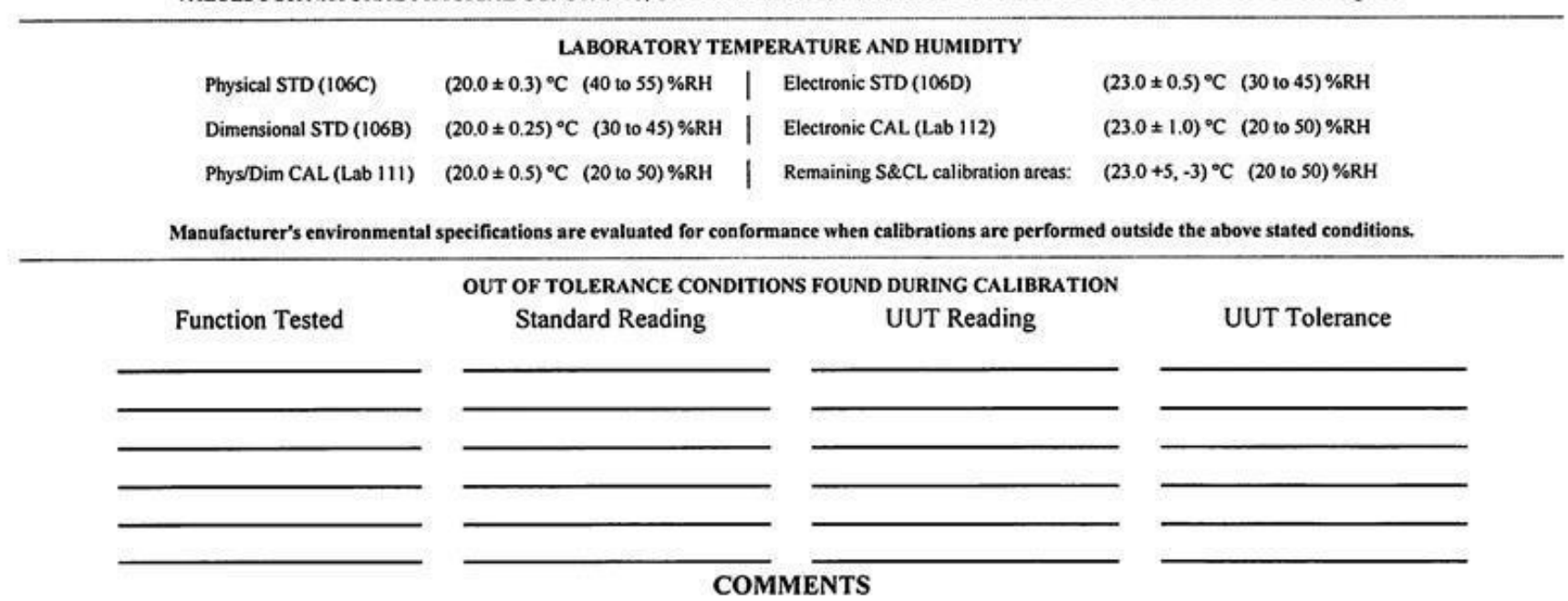

INITIAL CALIBRATION.

LIMITED: MUST USE NEW COEFFICIENTS GENERATED: A $=-9.890846965 \mathrm{E}-2$

B= -4.86336 
TEM-10200-1

$03 / 01 / 2012$

ENGINEERING CALCULATIONS AND ANALYSIS

Page A4 of A6

Rev. 06

Title: $\quad$ AGC-2 Specimen Load Calculations by Stack

ECAR No.: 2925

Rev. No.: 0

Project No.:

32138

Date: $02 / 10 / 2016$

\begin{tabular}{|c|c|c|c|c|c|}
\hline & & & RATION & IT DATA & \\
\hline & & & $1 / 27 / 2$ & & \\
\hline NAME: USER UNKNOWN & BADGE: 0 & PH: & AREA:? & BLDG: ? & RM:? \\
\hline
\end{tabular}

\begin{tabular}{|c|c|c|c|c|c|c|}
\hline \multirow{2}{*}{\multicolumn{2}{|c|}{$\begin{array}{l}\text { ID Number: } 727819 \quad \text { Mfr } \\
\text { Next Cal Due Date: } 6 / 7 / 2011\end{array}$}} & \multicolumn{2}{|c|}{ Mfr: HONEYWELL } & \multicolumn{2}{|l|}{ Model: $31-1000$} & \multirow{2}{*}{$\begin{array}{l}\text { Noun Name: LOAD CELL } \\
\text { AS-FOUND CONDITION }\end{array}$} \\
\hline & & & & ACTION PERFORMED & & \\
\hline Calibration Date: & $6 / 7 / 2010$ & 1 & $\square$ & Acceptance Test & 1 & In Tolerance \\
\hline Charge Level: & 12 & 2 & $\square$ & Calibration - SCL Specs & 2 & Out of Tolerance $>1 x<2 x$ \\
\hline \multicolumn{2}{|c|}{ Repair/Adj/etc C.L: 0} & 3 & $\square$ & Calibration - MFG Specs & 3 & Out of Tolerance $>2 x<3 x$ \\
\hline Material Amount: & 0 & 4 & $\square$ & Clean & 4 & Out of Tolerance $>3 x<5 x$ \\
\hline Charge Number: & $100911 \mathrm{C} 56$ & 5 & V & Limited Calibration & 5 & Out of Tolerance $>5 x$ \\
\hline Cal Work Inst ID: & $5748 \mathrm{P}$ & 6 & $\square$ & Functional Check & 6 & Out of Tolerance-Undetermined \\
\hline \multirow[t]{5}{*}{ Outside Vendor: } & & 7 & $\square$ & Performance Check & 7 & $\square$ Inoperative \\
\hline & & 8 & $\square$ & Modify & 8 & $\square$ Damaged \\
\hline & & 9 & $\square$ & Repair-needs Charge Level & 9 & $\square$ Not Used \\
\hline & & 10 & $\square$ & Other & 10 & $\square$ Not Determined \\
\hline & & & & & 11 & $\square$ Excessed \\
\hline Calibrated By: & Stan Zohner & SH: & 58146 & Phone: $526-2350$ & 12 & $\square$ Extension \\
\hline
\end{tabular}

CALIBRATION STANDARDS USED

\begin{tabular}{|l|l|l||l|l|l|l|l||}
\hline 350816 & 350815 & 375257 & & & & \\
\hline & & & & & & & \\
\hline & & & & & & \\
\hline
\end{tabular}

STANDARDS USED ARE TRACEABLE TO THE NATIONAL INSTITUTE OF STANDARDS AND TECHNOLOGY DERIVED FROM ACCEPTED VALUES FOR NATURAL PHYSICAL CONSTANTS, OR DERIVED FROM THE RATIO TYPE OF SELF CALIBRATION TECHNIQUES.

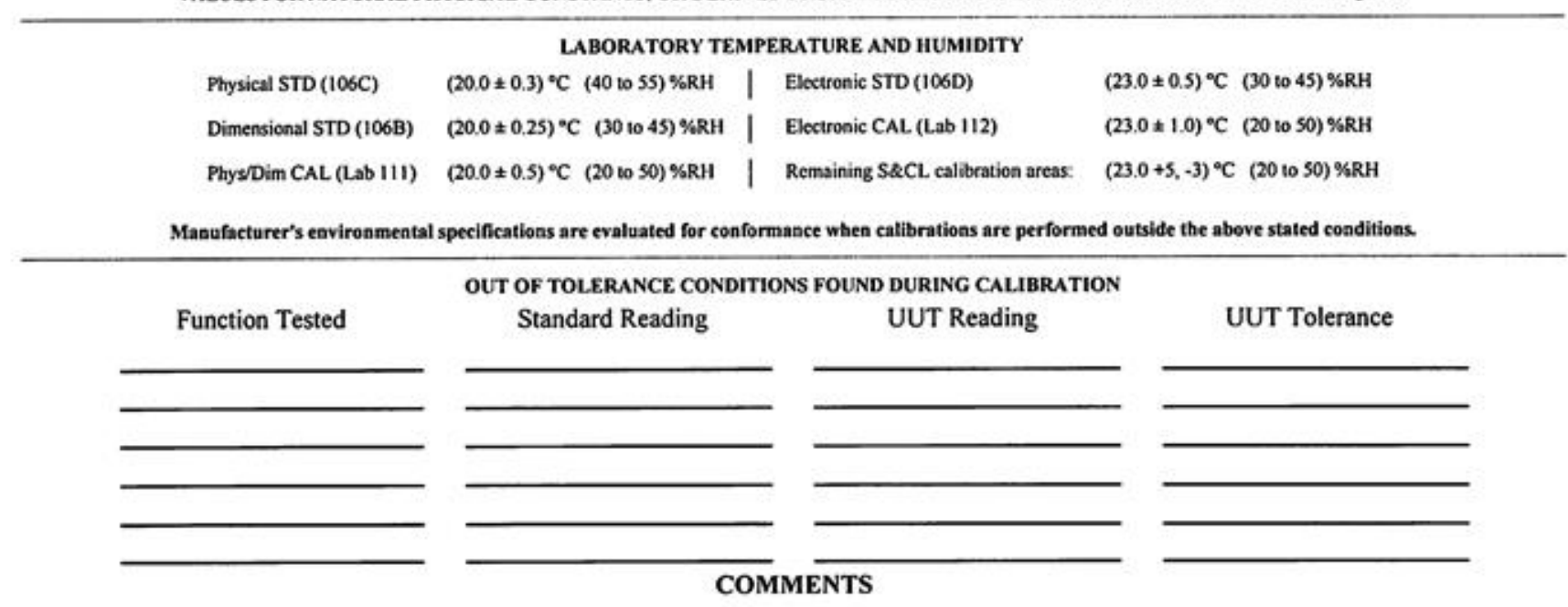

INITIAL CALIBRATION.

LIMITED: MUST USE NEW COEEEICIENTS GENERATED: Ao $-3.195322146 \mathrm{E}-1$

B= $-4.736679991 E+1$ C= $-8.210572535 E-4$, EXCITATION VOLTAGE 10 VDC, TENSION NOT CALIBRATED PER USER (SCOTT BARRIE) 
TEM-10200-1

$03 / 01 / 2012$

ENGINEERING CALCULATIONS AND ANALYSIS

Page A5 of A6

Rev. 06

Title: $\quad$ AGC-2 Specimen Load Calculations by Stack

$\begin{array}{lllll}\text { ECAR No.: } 2925 & \text { Rev. No.: } & 0 & \text { Project No.: } & 32138\end{array}$

Date: $02 / 10 / 2016$

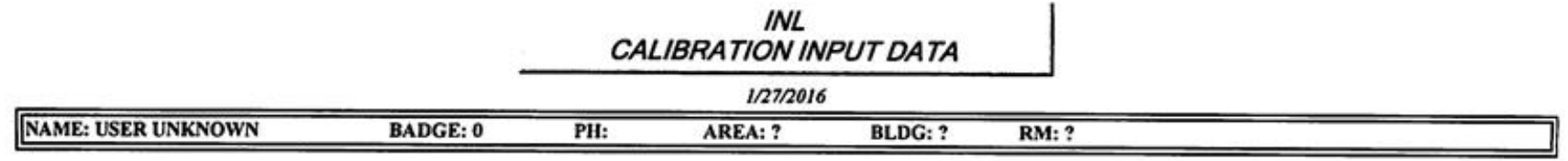

ID Number: $727820 \quad$ Mfr: HONEYWELL

Model: $31-1000$

Next Cal Due Date: 6/8/2011

ACTION PERFORMED

Noun Name: LOAD CELL Serial \#: 1295094

Calibration Date: 6/8/2010

Acceptance Test AS-FOUND CONDITION

Charge Level: $\quad 12$

Repair/Adj/etc C.L: 0

$2 \square$ Calibration-SCL Specs

Material Amount: 0

$3 \square$ Calibration-MFG Specs

1 In Tolerance

Charge Number: $\quad 100911 \mathrm{C} 56$

$4 \square$ Clean

Cal Work Inst ID: $5748 \mathrm{P}$

$5 \square$ Limited Calibration

$6 \square$ Functional Check

$7 \square$ Performance Check

$8 \square$ Modify

$9 \square$ Repair-needs Charge Level

$2 \bigcirc$ Out of Tolerance $>$ lx $<2 x$

Outside Vendor:

$10 \square$ Other

3 Out of Tolerance $>2 x<3 x$

$4 \bigcirc$ Out of Tolerance $>3 x<5 x$

$5 \bigcirc$ Out of Tolerance $>5 x$

6 Out of Tolerance-Undetermined

$7 \square$ Inoperative

$8 \square$ Damaged

$9 \square$ Not Used

$10 \square$ Not Determined

$11 \square$ Excessed

Calibrated By: Stan Zohner

S\#: 58146 Phone: 526-2350

$12 \square$ Extension

CALIBRATION STANDARDS USED

\begin{tabular}{|l|l|l|l|l|l|l|l|l||}
\hline 350816 & 350815 & 375257 & & & & & & \\
\hline & & & & & & & & \\
\hline & & & & & & & & \\
\hline
\end{tabular}

. STANDARDS USED ARE TRACEABLE TO THE NATIONAL INSTITUTE OF STANDARDS AND TECHNOLOGY DERIVED FROM ACCEPTED VALUES FOR NATURAL PHYSICAL CONSTANTS, OR DERIVED FROM THE RATIO TYPE OF SELF CALIBRATION TECHNIQUES.

LABORATORY TEMPERATURE AND HUMIDITY

\begin{tabular}{|c|c|c|c|}
\hline Physical STD (106C) & $(20.0 \pm 0.3)^{\circ} \mathrm{C}$ (40 to 55)\%RH & Electronic STD (106D) & $(23.0 \pm 0.5)^{\circ} \mathrm{C} \quad(30$ to 45$) \% \mathrm{RH}$ \\
\hline Dimensional STD (106B) & $(20.0 \pm 0.25)^{\circ} \mathrm{C}$ (30 to 45$) \% R H$ & Electronic CAL (Lab 112) & $(23.0 \pm 1.0)^{\circ} \mathrm{C} \quad(20$ to 50$) \% R H$ \\
\hline Phys/Dim CAL (Lab III) & $20.0 \pm 0.5)^{\circ} \mathrm{C}(20$ to 50$) \% R H$ & Remaining $S \& C L$ calibration areas: & $(23.0+5,-3)^{\circ} \mathrm{C}(20$ to 50$)$ \\
\hline
\end{tabular}

Manufacturer's environmental specifications are evaluated for conformance when calibrations are performed outside the above stated conditions.

Function Tested

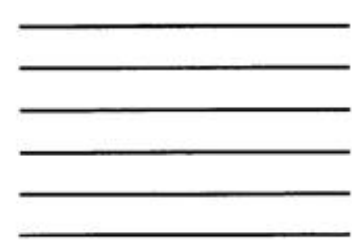

OUT OF TOLERANCE CONDITIONS FOUND DURING CALIBRATION

$$
\text { Standard Reading UUT Reading }
$$

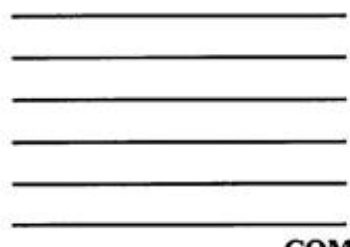

\section{COMMENTS}
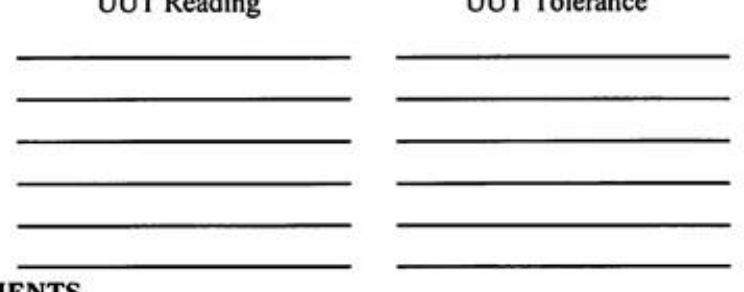

INITIAL CALIBRATION,

LIMITED: MOST USE NEW COEFFICIENTS GENERATED: $A=-2.107274760 \mathrm{E}-1$

Ba $-4.983276423 \mathrm{E}+1 \mathrm{C}=4.150739071 \mathrm{E}-3$, EXCITATION VOLTAGE $10 \mathrm{VDC}$, TENSION NOT CALIBRATED PER USER (SCOTT BARRIE)

QA4 159959 
TEM-10200-1

$03 / 01 / 2012$

ENGINEERING CALCULATIONS AND ANALYSIS

Page $A 6$ of $A 6$

Rev. 06

Title: $\quad$ AGC-2 Specimen Load Calculations by Stack

$\begin{array}{lllll}\text { ECAR No.: } 2925 & \text { Rev. No.: } & 0 & \text { Project No.: } & 32138\end{array}$

Date: $02 / 10 / 2016$

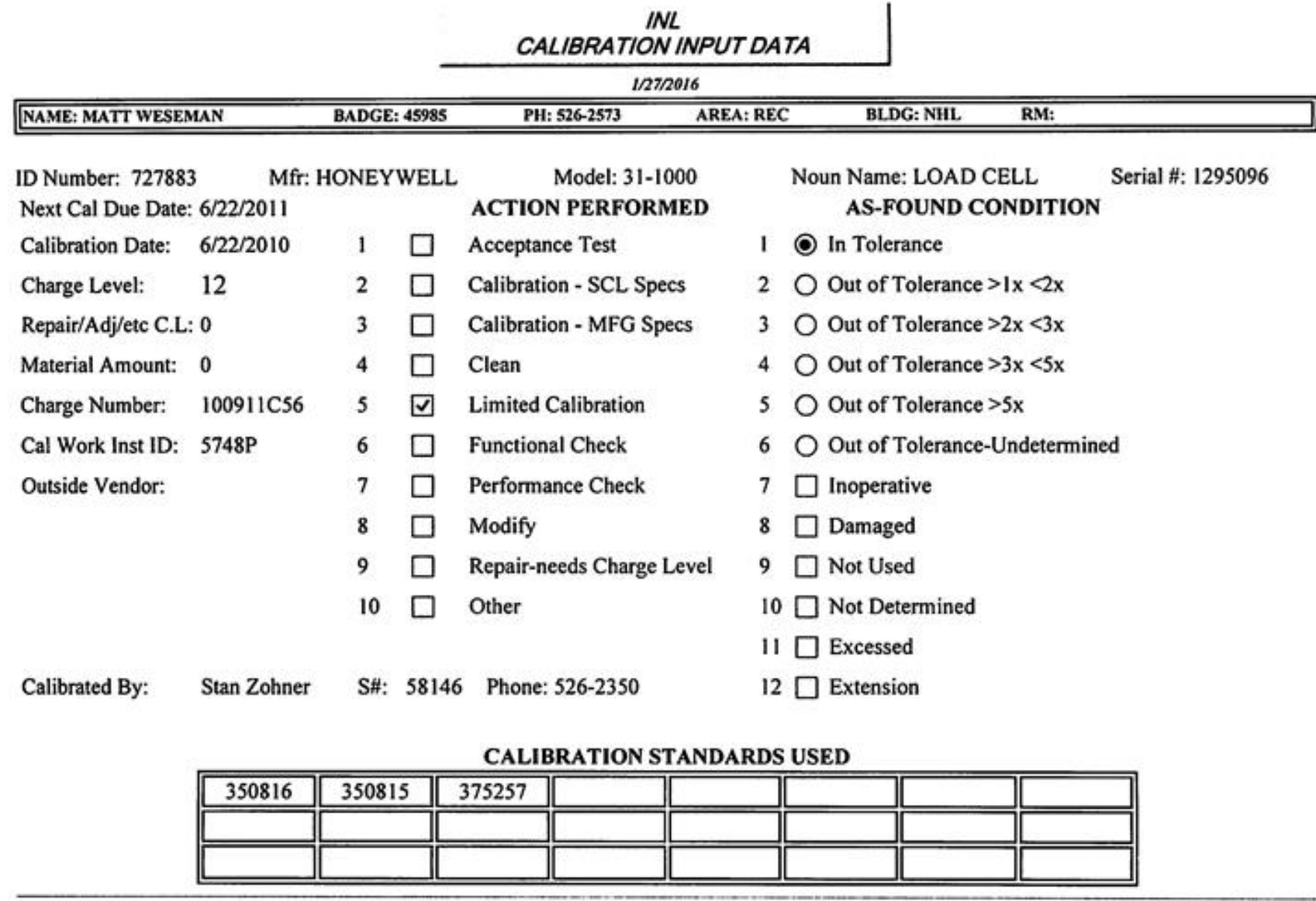

STANDARDS USED ARE TRACEABLE TO THE NATIONAL INSTITUTE OF STANDARDS AND TECHNOLOGY DERIVED FROM ACCEPTED VALUES FOR NATURAL PHYSICAL CONSTANTS, OR DERIVED FROM THE RATIO TYPE OF SELF CALIBRATION TECHNIQUES.

LABORATORY TEMPERATURE AND HUMIDITY

$\begin{array}{llll}\text { Physical STD }(106 \mathrm{C}) & (20.0 \pm 0.3)^{\circ} \mathrm{C}(40 \text { to } 55) \% \mathrm{RH} \quad \text { Electronic STD }(106 \mathrm{D}) \quad(23.0 \pm 0.5)^{\circ} \mathrm{C}(30 \text { to } 45) \% \mathrm{RH}\end{array}$

Dimensional STD (106B) $\quad(20.0 \pm 0.25)^{\circ} \mathrm{C}(30$ to 45$) \% R H \quad$ Electronic CAL (Lab 112) $\quad(23.0 \pm 1.0)^{\circ} \mathrm{C}(20$ to 50$) \% R H$

Pbys/Dim CAL (Lab III) $\quad(20.0 \pm 0.5)^{\circ} \mathrm{C}\left(20\right.$ to 50)\%RH | Remaining S\&CL calibration areas: $\quad(23.0+5,-3){ }^{\circ} \mathrm{C}(20$ to 50$) \%$ RH

Manufacturer's environmental specifications are evaluated for conformance when calibrations are performed outside the above stated conditions.

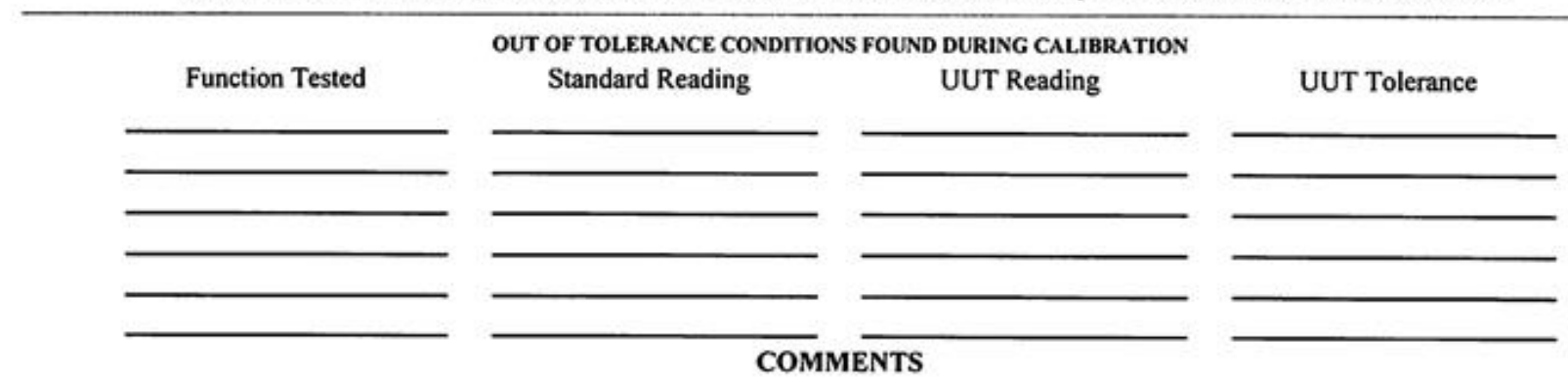

INITIAL CALIBRATION.

LIMITED: MUST USE NEW COEFEICIENTS GENERATED: A= $-1.278356755 E-1$

$B=-4.599555227 \mathrm{E}+1 \mathrm{C}=4.479399402 \mathrm{E}-3$, EXCITATION VOLTAGE $10 \mathrm{VDC}$, TENSION NOT CALIBRATED PER USER (SCOTT BARRIE) QA9 160340 